Check for updates

Montreal, Canada

Cite this as: BMJ 2021;372:n874 http://dx.doi.org/10.1136/bm..n874 Published: 31 March 2021

\title{
Covid-19: Doctor charged with murder as police investigate multiple patient deaths in Canadian hospital
}

\section{Owen Dyer}

A specialist in internal medicine has been charged with first degree murder following a cluster of deaths in a Canadian hospital that were initially attributed to covid-19.

Brian Nadler, 35, was arrested on 25 March at Hawkesbury and District General Hospital near Ottawa. Patient Albert Poidinger, 89, was declared dead the same day. Nadler was charged with his murder the next day in a remote court appearance. Nadler maintains his innocence, his lawyer said.

On the morning of Nadler's arrest, the hospital had announced a covid-19 outbreak, its second this month, and reported "five deaths related to the covid-19 virus." Sixteen admitted patients and five staff had tested positive, the hospital announced. ${ }^{1}$

Police named the alleged murder victim on 29 March, but Ontario Provincial Police spokesman Bill Dickson would not confirm that Poidinger was once of Nadler's patients. Dickson told CBC that other patient deaths are being investigated, but he refused to give numbers or details. The Ottawa Citizen has since reported that the deaths under investigation are the five covid-19 patients and that the drugs used is a key focus. According to its sources, the newspaper said, a hospital colleague reported Nadler to the police. ${ }^{2}$

It is not clear how long Nadler had worked at the hospital. He has been licensed to work in Ontario for a year. He was a resident at the University of Saskatchewan's medical school from 2014 to 2018, then trained in geriatric medicine at the University of Nevada. He is reported ${ }^{3}$ to have faced two professional conduct charges in Saskatchewan, one involving record keeping and the other for allegedly calling a female colleague a "bitch" and telling someone that he "felt like slapping" that colleague. A former colleague from Nevada, Ahmed Hanfy, told the Canadian press ${ }^{4}$ that Nadler "is one of those people who argues a lot," but added that he was shocked to learn of the murder charge.

In March last year, as covid-19 cases began to soar in Canada, a Twitter account with Nadler's name and photo sent a tweet to actor Ryan Reynolds, warning about the virus. The tweet said: "I am a front line physician in Canada requesting you to tell your fans and followers to self-isolate immediately. We do not have enough ventilators for even the young \& healthy! - Dr Nadler, Ontario internist."5

In 2013, Nadler wrote an article for the Alberta Medical Association on creating a supportive work environment. ${ }^{6}$ "The frequency of mental health issues in our profession is finally beginning to be recognised," he wrote. "We now know, based on substantial research, that physicians, residents, and medical students have disproportionately higher rates of clinical depression, anxiety disorders, severe burnout, substance abuse, and suicide compared to the general population." He concluded, "The role of each of us as physicians is to create a culture where open discussions of mental health issues are encouraged and normalised. Most importantly, we must remember to start with ourselves."

Hawkesbury and District General Hospital. Press release: Covid-19 outbreak declared on March 25 2021. 25 March 2021. https://hgh.ca/update-on-newcovid-19-outbreak-at-hgh.

2 Crawford B, Payne E. Hawkesbury homicide investigation focuses on deaths of five covid-19 patients. 29 March 2021. Ottawa Citizen. https://ottawacitizen.com/news/local-news/victim-in-hawkesbury-hospital-homicide-was89-year-old-man-from-quebec.

3 College suspends doctor's licence after murder charge following death of hospital patient. CBC News. 30 March 2021. www.cbc.ca/news/canada/ottawa/brian-nadler-licence-suspended-college-1.5970639.

4 Victor J. Ex-colleague of Ontario doctor Brian Nadler shocked to learn of murder charge. Toronto Star. 27 March 2021. www.thestar.com/news/canada/2021/03/27/ex-colleague-of-ontario-doctor-brian-nadler-shocked-tolearn-of-murder-charge.html.

5 Dr Brian Nadler. 17 March 2020. https://twitter.com/NadlerDr/status/1239938802044542979.

6 Nadler B. Do you want to create a supportive work environment? 22 June 2013. www.albertadoctors.org/3128.aspx.

This article is made freely available for use in accordance with BMJ's website terms and conditions for the duration of the covid-19 pandemic or until otherwise determined by BMJ. You may use, download and print the article for any lawful, non-commercial purpose (including text and data mining) provided that all copyright notices and trade marks are retained. 